\title{
Efektivitas Pembelajaran Matematika Secara Online Di SMK TI Bali Global Denpasar Pada Masa Pandemi Covid-19
}

\author{
Evi Dwi Krisna*, Ni Kadek Suryati \\ STMIK STIKOM INDONESIA,Denpasar, Bali 80225 \\ *Email: evidwikrisna@gmail.com \\ DOI: https://doi.org/10.33369/pendipa.6.1.209-217
}

\begin{abstract}
[The Effectiveness of Online Mathematics Learning at Vocational High School of IT Bali Global Denpasar during the Covid 19 Pandemic].The purpose of this study was to determine the effectiveness of online learning using online media during the covid-19 pandemic in mathematics and find the student's problems that occur. This study is a descriptive quantitative study with the population being all students Vocational High School of IT Bali Global Denpasar who were tought mathematics using the online method. The research sample was 66 students of class X RPL who were selected using simple random sampling technique. Collecting data using a questionnaire with a Google form application, and data analysis using descriptive statistics. In this research, evaluating the effectiveness in this study using indicators of student satisfaction and understanding in the implementation of online learning. From the satisfaction indicator, it was found that 37,9\% felt quite satisfied, $27.7 \%$ answered satisfied, and $7.6 \%$ answered very satisfied, and only $25.8 \%$ answered less satisfied and $6.1 \%$ answered very dissatisfied. From the indicators of student understanding, $43.9 \%$ agreed with the statement that online learning was easy to understand, and 13.6\% answered strongly agree. On the other hand, 33.3\% disagreed and 9.1\% strongly disagreed. For student's problems that occur, it was found that $68.2 \%$ answered quota constraints for the internet and $22.7 \%$ answered signal problems or poor internet connections. So from this study it can be concluded that online learning with the online media system at Vocational High School of IT Bali Global Denpasar is running quite effectively. However, improvements in the quality of learning must be carried out and the points that become student's problems must be found solutions, so that the effectiveness of learning will be better in the future.
\end{abstract}

Keywords: Online learning, covid-19 pandemic, effectivity.

\begin{abstract}
ABSTRAK
Tujuan dari penelitian ini adalah untuk mengetahui efektivitas pembelajaran daring menggunakan media online selama pandemi covid-19 pada mata pelajaran matematika, sekaligus mengetahui permasalahan yang terjadi dan menjadi kendala siswa. Penelitian ini merupakan penelitian kuantitatif deskriptif dengan populasi adalah seluruh peserta didik SMK TI Bali Global Denpasar yang mendapat mata pelajaran matematika menggunakan metode daring. Sampel penelitian adalah 66 siswa kelas X RPL yang dipilih menggunakan teknik simple random sampling. Pengumpulan data menggunakan kuesioner dengan aplikasi Google form, dan analisis data menggunakan statistik deskriptif. Penilaian efektivitas dalam penelitian ini memakai indikator kepuasan dan pemahaman siswa dalam pelaksanaan pembelajaran online. Dari indikator kepuasan didapatkan hasil 37,9\% merasa cukup puas, 27,7\% menjawab puas, dan 7,6\% menjawab sangat puas, dan hanya 25,8\% menjawab kurang puas dan 6,1\% menjawab sangat tidak puas. Dilihat dari indikator pemahaman siswa bahwa, 43,9\% menyatakan setuju dengan pernyataan bahwa pembelajaran daring mudah untuk dimengerti, dan 13,6\% menjawab sangat setuju. Disisi lain sebanyak 33,3\% menyatakan tidak setuju dan sebanyak 9,1\% menyatakan sangat tidak setuju. Untuk permasalahan yang dihadapi siswa , 68,2\% menjawab kendala quota untuk internet dan 22,7\% menjawab permasalahan sinyal atau koneksi internet yang buruk. Jadi dari penelitian ini dapat disimpulkan bahwa pembelajaran online dengan sistem daring di SMK TI Bali Global Denpasar berjalan dengan cukup
\end{abstract}


efektif. Namun demikian perbaikan dan peningkatan kualitas pembelajaran harus terus dilakukan dan poin yang menjadi permasalahan siswa harus dicari solusinya, sehingga efektivitas pembelajaran menjadi semakin lebih baik kedepannya.

Kata kunci: Pembelajaran online, pandemi covid- 19, efektivitas.

\section{PENDAHULUAN}

Dunia pendidikan sekarang ini dihadapkan pada era baru terkait adanya pandemi Covid 19. Covid 19 merupakan virus yang pertama kali diidentifikasi di Wuhan China pada bulan November 2019. Selain sangat mematikan, virus ini memiliki kemampuan penularan yang sangat cepat sehingga saat ini menjadi pandemi dunia. Sampai bulan Maret 2021 ini, virus ini telah menyebar ke hampir semua negara dan telah menginfeksi 122.536 .880 orang, dengan jumlah kematian 2.703 .780 orang (World Health Organization, Covid-19 Weekly Epidemiological Update)

Mempertimbangkan berbahayanya dan cepatnya penyebaran dari virus ini, sesuai pedoman WHO, hampir semua negara di dunia menerapkan program-progam yang bertujuan untuk mencegah penularan dan melawan virus ini. Salah satu cara yang dilakukan adalah dengan melakukan pembatasan interaksi masyarakat yang diterapkan dengan istilah physical distancing. Namun, kebijakan physical distancing tersebut menjadi kontroversi di dunia karena menghambat laju pertumbuhan dalam berbagai bidang kehidupan, baik bidang ekonomi, sosial, dan tentu saja pendidikan. Sektor pendidikan salah satu faktor yang sangat krusial, mengingat pentingnya dunia pendidikan bagi perkembangan bangsa dan negara Indonesia. Di Indonesia, Sistem Pendidikan Nasional diatur dalam UU Nomor 20 Tahun 2003, pasal 3, disebutkan bahwa pendidikan nasional berfungsi mengembangkan kemampuan dan membentuk watak serta peradaban bangsa yang bermartabat dalam rangka mencerdaskan kehidupan bangsa. Pada masa pandemi Covid 19 ini, sebagian besar negara, termasuk juga Indonesia mengambil kebijakan meliburkan sekolah dengan proses belajar mengajar di sekolah dikonversi menjadi pembelajaran jarak jauh dari rumah, yang disebut juga dengan Daring (Dalam Jaringan) atau Work From Home (WFH). Di Indonesia, Kebijakan WFH tertuang dalam Surat Edaran Menteri Pendayagunaan Aparatur Negara dan Reformasi Birokrasi (PAN \& RB) Nomor 50/2020 tentang Perubahan Kedua atas Surat Edaran Menteri PAN \& RB Nomor 19/2020 tentang Penyesuaian Sistem Kerja Aparatur Sipil Negara dalam Upaya Pencegahan Penyebaran Covid-19 di Lingkungan Instansi Pemerintah.

Aturan dari pemerintah ini mewajibkan guru maupun siswa untuk beradaptasi terhadap sistem pembelajaran WFH yang notabene sangat baru untuk sebagian besar guru maupun siswa di Indonesia. Disinilah terjadi problematika pada sistem pembelajaran ini, salah satunya adalah hal mendasar dalam proses pembelajaran yaitu kemampuan adaptasi siswa untuk memahami materi yang diberikan guru melalui media online dalam proses pembelajaran WFH yang diterapkan di masa pandemi ini. Meskipun demikian pembelajaran online sebenarnya bukan hal yang baru dalam pembelajaran. Beberapa penelitian sebelumnya seperti yang dikemukakan oleh Gheytasi (2015), menyatakan bahwa pembelajaran dengan media online seperti penggunaan internet dan gadget sangat membantu dalam proses pembelajaran. Demikian juga yang dikemukakan oleh Kuntarto (2017), dalam penelitiannya menyatakan bahwa sistem pembelajaran online yang interaktif, efektif digunakan dalam proses pembelajaran dan perkuliahan. Namun di sisi lain, siswa di Indonesia banyak yang belum terbiasa dengan pembelajaran online. Hal inilah yang menjadi tantangan bagi siswa dan tenaga penajara agar siswa mampu beradaptasi dengan cepat sehingga pembelajaran tetap dapat berjalan baik dalam masa pandemi ini.

Salah satu pelajaran yang menjadi momok menakutkan adalah mata pelajaran matematika. Sebelum pandemi saja matematika diaggap merupakan pelajaran yang sangat sulit oleh siswa. Padahal matematika merupakan salah satu bidang studi yang sangat penting dan memegang peranan strategis bagi peserta didik 
maupun bagi pengembangan bidang keilmuan yang lain), dan merupakan alat utama untuk memberikan cara berpikir, yaitu menyusun pemikiran yang jelas, tepat, teliti, dan taat azaz (Suherman, 2003). Di era pembelajaran WFH ini tentu saja diperlukan effort yang lebih baik dari guru maupun siswa agar tujuan pembelajaran dapat tercapai dengan baik. Seperti yang dikemukakan oleh Auliya (2016), matematika dianggap sebagai pelajaran yang sulit karena karakteristik matematika yang bersifat abstrak, logis, sistematis, dan penuh dengan lambang serta rumus yang membingungkan siswa sehingga dituntut kreativitas guru mata pelajaran matematika untuk mengembangkan pembelajarannya, baik dalam hal metode maupun media yang digunakan. Namun dalamn era pembelajaran online yang dilakukan secara daring, tentu saja hal ini menjadi lebih sulit dan menjadi tantangan tersendiri untuk pengajar mata pelajaran matematika.

Media yang banyak digunakan untuk sistem pelajaran daring ini adalah whatsapp group, google classroom, microsoft team, website e-learning, quizzes, telegram, dll. Beberapa studi sebelumnya telah mempelajari terkait penggunaan media dalam pembelajaran. Dalam penelitian yang dilakukan oleh Hanum (2013) di SMK Telkom Sandhy Putra Purwokerto dikatakan bahwa secara keseluruhan dapat disimpulkan bahwa pelaksanaan pembelajaran e-learning sebagai media pembelajaran yang efektif dengan tingkat kecenderungan $77,27 \%$. Demikian juga yang dikemukakan oleh Krisna (2020), dalam studinya di STMIK STIKOM Indonesia, dari hasil penelitian menunjukkan bahwa implementasi model Problem Based Learning Berbantuan Google Classroom berhasil meningkatkan prestasi belajar matematika mahasiswa. Di SMK TI Global Bali Denpasar, selama pandemi sistem pembelajaran dengan menggunakan, google clasroom microsoft team dan website e-learning. Materi diberikan dalam bentuk video singkat, dan bahan berupa file materi untuk siswa. Demikian juga evaluasi dilakukan melalui media tersebut. Diharapkan meskipun dilakukan secara online, proses belajar mengajar tetap dapat berjalan dengan baik tanpa mengurangi kualitas pembelajaran.

https://ejournal.unib.ac.id/index.php/pendipa
Meskipun dalam evaluasi pembelajaran sekilas terlihat dapat berjalan dengan baik dan tujuan pembelajaran dapat tercapai dengan baik, terdapat pro dan kontra di kalangan siswa, ada yang merasa tidak mengalami kendala dalam menjalani metode pembelajaran online, namun tidak sedikit juga siswa yang mengeluh dengan metode ini, baik mengeluh karena biaya yang naik karena harus membeli kuota internet, kesulitan dalam menggunakan aplikasi daring dan merasa kesulitan dalam memahami pelajaran secara online. Di sisi lain pamdemi Covid-19 belum menunjukkan tanda-tanda berakhir dan kemungkinan pembelajaran online dengan metode daring masih akan diterapkan sampai jangka waktu yang masih belum bisa ditentukan. Terkait hal tersebut proses pelaksanaan pembelajaran daring tersebut perlu dilakukan suatu studi untuk mengetahui efektivitas yang berbasis data dari sistem pembelajaran daring yang dilakukan selama masa pandemi ini. Selain itu, hal ini juga bertujuan untuk mendapat masukan dari siswa secara langsung mengenai langkah-langkah yang dapat diambil untuk perbaikan proses pembelajaran daring ini, sehingga tidak mengurangi mutu pembejalaran serta akan tetap dihasilkan output yang baik meskipun terdapat perubahan dari sistem pendidikan dari tatap muka menjadi pembelajaran online. Hal ini yang menjadi dasar pertimbangan penulis untuk melakukan studi deskriptif untuk mengetahui efektivitas dari sistem pembejarahn matematika yang dilakukan secara daring di kelas X, SMK TI Global Denpasar ditijau dari pemahan siswa.

\section{METODE PENELITIAN \\ Waktu dan Lokasi Penelitian}

Penelitian ini berlangsung dari bulan Januari sampai Maret 2021 di SMK TI Global Denpasar

\section{Rancangan Penelitian}

Penelitian ini merupakan suatu penelitian kuantitatif deskriptif yang bertujuan untuk mengetahui gambaran efektivitas pembelajaran daring menggunakan media online pada mata pelajaran matematika di kelas X SMK TI Global Denpasar. Populasi penelitian yakni seluruh peserta didik SMK TI Global Denpasar yang diajar mata pelajaran matematika menggunakan metode daring. Siswa yang menjadi subjek penelitian berjumlah sebanyak 66 siswa kelas X 
SMK TI Global Denpasar yang dipilih menggunakan teknik simple random sampling dengan mempertimbangkan homogenitas populasi.

\section{Teknik Pengumpulan Data}

Teknik pengumpulan data menggunakan kuisioner. Pengisian kuisioner ini dilakukan secara online dengan menggunakan google form. Kuisioner berisikan beberapa pertanyaan yang ditujukan untuk mengetahui efektifitas pembelajaran online dengan metode daring selama pandemi covid 19.

\section{Metode Analisis Data}

Teknik analisis data menggunakan statistik deskriptif dengan bantuan komputerisasi yang ditinjau dari hasil kuisioner yang telah diisi oleh subjek penelitian.

\section{HASIL DAN PEMBAHASAN}

Untuk pengumpulan data, peneliti mengajukan beberapa pertanyaan yang sangat relavan untuk diisi secara jujur oleh responden yang secara sukarela mau mengisi kuesioner yang sudah disiapkan. Berikut ini beberapa pertanyaan yang diajukan kepada responden:

1. Bagaimana pendapat anda mengenai sistem pembejaran secara online dengan metode daring selama masa pandemi covid - 19?

Pada pertanyaan pertama dari kuisioner, siswa sebagai subjek penelitian diminta menjawab pertanyaan dengan memilih salah satu dari 5 jawaban yang tersedia, dari tingkat sangat puas sampai sangat tidak puas. Dari pertanyaan ini akan diketahui tingkat kepuasan siswa terhadap sistem pembelajaran online dengan metode daring yang telah berlangsung hampir setahun selama pandemi.

Berdasarkan hasil jawaban dari pertanyaan pertama, dapat diketahui bahwa sebagian besar menjawab cukup puas dengan pembelajaran secara online selama masa pandemi, yaitu sebesar $37,9 \%$. Terdapat $22,7 \%$ siswa yang menjawab puas, dan $7,6 \%$ yang menjawab sangat puas dengan sistem pembelajaran secara online ini. Di sisi lain, terdapat $25,8 \%$ menjawab kurang puas dan $6,1 \%$ menjawab sangat tidak puas dengan pembelajaran yang dilakukan secara online selama masa pandemi.

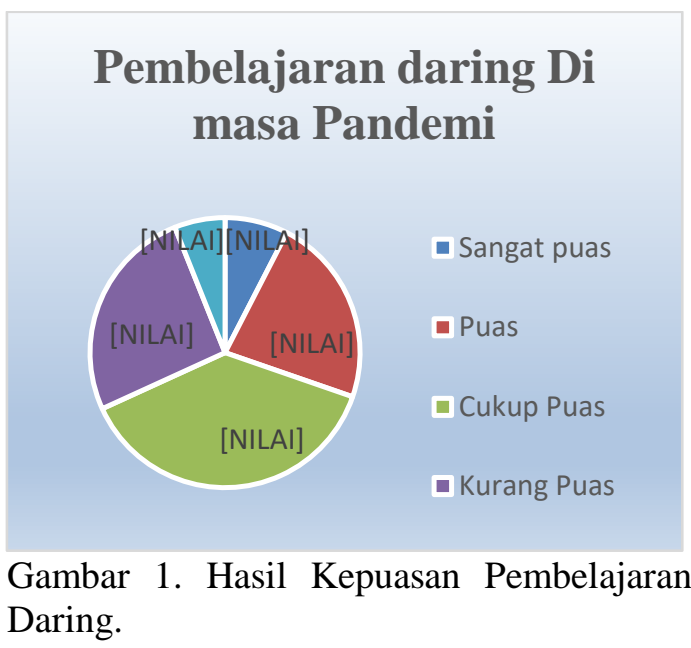

Dari sini, kita dapat mengetahui bahwa separuh lebih dari subjek penelitian merasa cukup puas dengan sistem pembelajaran secara online selama pandemi. Hal ini tentu menjadi indikator yang baik untuk sekolah dan tenaga pendidik, bahwa telah membuat dan melaksanakan sistem pembelajaran dengan baik. Namun demikian hal ini perlu terus ditingkatkan agar sistem pembelajaran semakin membaik kedepannya. Masih adanya ketidakpuasan dari beberapa siswa, dapat menjadi bahan evaluasi bersama untuk perbaikan, baik secara kualitas maupun pertimbangan diperlukannya inovasi-inovasi yang mampu meningkatkan kepuasan dan antusiasme dari siswa kedepannya.

2. Media apa saja yang digunakan dalam pembelajaran daring di SMK anda?

Pertanyaan ini berujuan untuk mengetahui jensi platform pembelajaran online yang digunakan di sekolah yang menjadi tempat penelitian. hal ini menjadi substansial mengingat tiap-tiap paltform memiliki fitur dan spesifikasi yang berbeda dalam menunjang proses pemnbelajaran daring ini. Sebagai contoh ada platform yang dianggap lebih mudah digunakan, atau ada platform yang bisa digunakan pembelajaran yang lebih interaktif debandingkan paltform aplikasi lain seperti adanya fitur 
pembelajaran video dua arah dan sebagainya.

Di SMK TI Global Bali Denpasar, sistem pembelajaran online selama masa pandemi menggunakan metode Sinkronus dan Asinkronus. Media yang digunakan untuk Asinkronus adalah E-learning sedangkan untuk Sinkronus dengan Microsoft Team. Kedua media ini dipakai secara bergantian masing-masing selama seminggu. Seperti yang telah dibahas sebelumnya tiap media memiliki kelebihan dan kekurangan masing-masing. E-learning merupakan suatu media berupa website yang memungkian terjadinya suatu interaksi baik berupa video, chat, ataupun berupa file-file. Ditinjau dari definis, menurut Chandrawati SR (2010) E-learning merupakan suatu proses pembelajaran yang memanfaatkan teknologi informasi berupa komputer yang dilengkapi dengan sarana telekomunikasi (internet, intranet, ekstranet) dan multimedia (grafis, audio, video) sebagai media utama dalam penyampaian materi dan interaksi antara pengajar (guru/dosen) dan pembelajar(siswa/mahasiswa).

Pembelajaran elektronik atau E-Learning ini telah dimulai pada tahun 1970-an. Seperti yang telah dibahas sebelumnya, dalam hal proses pembelajaran online, media ini memungkinkan untuk guru mengirimkan materi pembelajaran berupa file-file, serta memungkinkan diadakan kuis dan evaluasi atau ujian dari media ini serta adanya bank soal yang memudahkan siswa dan guru dalam pembelajaran. Media diskusi interaktif juga disediakan berupa fitur chat jika ada yang ingin siswa sampaikan atau ditanyakan kepada guru. Menurut Sari (2015) E-learning merupakan pembelajaran yang menggunakan fasilitas kecanggihan TIK yang memberikan kemudahan bagi pengguna untuk belajar mandiri, dimana saja, kapan saja, sehingga mendorong mereka senang belajar dan berupaya meningkatkan kompetensi belajarnya. Namun demikian media ini belum bisa memberi fitur interaktif video 2 arah, dimana siswa dan guru bisa bertatap muka secara virtual. Namun kelemahan $E$ - learning ini dapat ditutupi dengan medai aplikasi Microsoft Team yang memungkinkan guru dan siswa dapat berinteraksi 2 arah secara virtual menggunakan video interaktif. Dengan penggunakan 2 media secara bergantian, pihak sekolah berharap siswa tidak jenuh dalam belajar dan siswa dapat memahami materi dengan baik. Pembelajaran juga diharapkan dapat berjalan baik dan menarik, sehingga tujuan pembelajaran dapat tercapai meskipun terkendala kondisi pandemi. Dari penelitian oleh Situmorang (2020) minat belajar siswa dengan penggunaan Microsoft Team adalah sangat baik $(85,46 \%)$. Dari sisi tenaga pengajar, penelitian oleh Widiyarso TH (2021) menyatakan bahwa Microsoft Team efektif dalam memahami dan mengevaluasi persepsi guru untuk memastikan pengajaran dan pembelajaran yang berkualitas melalui Microsoft Team. Jadi selain baik untuk siswa, guru-guru juga diharapkan dapat menggunakan Microsoft Team dengan baik dan dapat memaksimalkan proses pembelajaran dengan menggunakan media ini.

3. Apa yang menjadi kendala dalam mengikuti pembelajaran daring? Sebutkan!

Pertanyaan ketiga adalah pertanyaan terbuka dimana siswa dapat menyampaikan secara bebas hal yang paling menjadi kendala dan permalahan selama proses pembalajaran daring. Siswa pun diperbolehkan menjawab tidak ada jika memang siswa merasa tidak mengalami masalah yang berarti selama menjalani pembejalaran daring. Dari pertanyaan ini, peneiliti dapat mengetahui kendala terbesar apa yang dihadapi siswa dalam menjalani proses pembejalaran daring ini, sehingga selain menjadi gambaran dan evaluasi oleh pihak sekolah, juga dapat menjadi dasar untuk mencari solusi dari permasalahan-permasalahan tersebut.

Pada pertanyaan ini, hampir sebagian besar siswa yaitu sebanyak $68,2 \%$ siswa menjawab kendala quota untuk internet. Para siswa tentu harus menyiapkan uang lebih untuk membeli quota internet yang cukup agar sistem pembalajaran dapat 
berjalan dengan baik. Permasalahan selanjutnya yang menjadi kendala bagi siswa dalam pembelajaran online ini adalah permsalahan sinyal atau koneksi internet yang buruk. Hal ini dikemukakan subjek penelitian sebesar 22,7\%. Beberapa siswa yang belajar online dari rumah dimana lokasinya kurang terjangkau sinyal operator komunikasi, tentu akan sangat terganggu karena untuk pembelajaran online dapat berjalan dengan baik, diperlukan sinyal yang baik untuk mendukung hal tersebut. Permasalahan selanjutnya sebesar $6,1 \%$ adalah siswa merasa kurang mengerti materi yang diajarkan. Siswa kesulitan untuk belajar secara mandiri melalui media pembelajaran online baik berupa tatap muka melalui video, menonton video pembelajaran, ataupun membaca materi yang telah dikirim guru kepada siswa. Sisanya sebanyak 3,\% menjawab kurang motivasi dan semangat dalam belajar karena tidak ada guru yang mengawasi secara langsung dalam belajar.

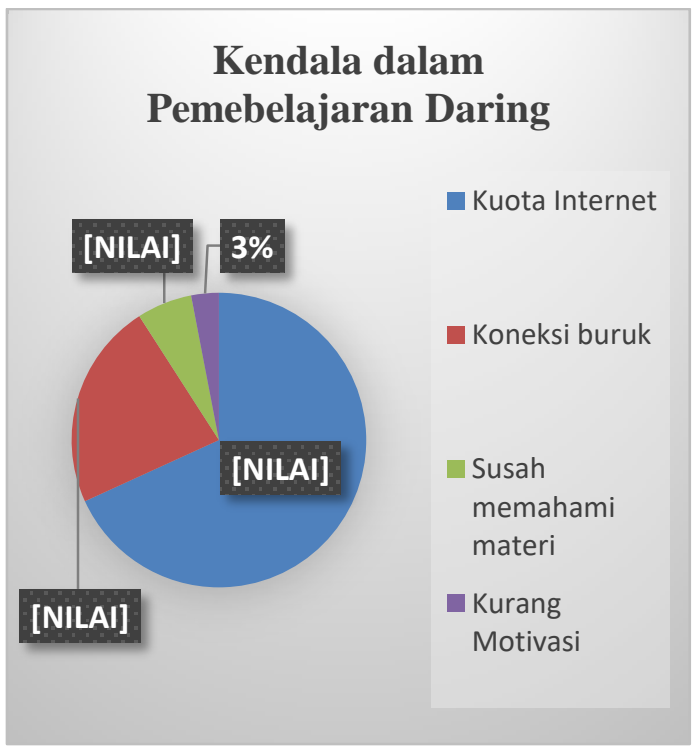

Gambar 2. Kendala dalam Pembelajaran Daring.

4. Metode pembelajaran daring apa yang paling anda sukai? Sebutkan!

Meskipun pembelajaran dilakukan secara daring, namun ada beberapa teknik atau metode yang dapat digunakan dalam sistem pelajaran online. Adapun seperti dengan ceramah oleh guru, diskusi, video interaktif, kuis, penugasan kelompok, dan lain lain. Pertanyaan ini bertujuan untuk mengetahui metode mana yang paling disukai oleh siswa. Dengan mengoptimalkan metode yang disukai siswa, diharapkan siswa menjadi lebih tertarik untuk belajar, membuat suasana pembelajaran lebih aktif sehingga tujuan pembelajaran dapat tercapai dengan hasil yang baik.

Metode belajar daring yang paling diskukai oleh siswa adalah pembelajaran dengan video interaktif dengan media aplikasi ms-team yaitu sebanyak $78,78 \%$. Dengan bertatap muka secara virtual dengan fitur ms-team ini, pembelajaran 2 arah yang interaktif dari guru ke siswa dapat memudahkan siswa menerima dan memahami materi dan pembelajaran yang diberikan. Metode selanjutnya yang paling disukai adalah metode e-learning, yaitu sebesar $12,12 \%$. Meskipun media e-learning tidak bisa memfasilitasi tatap muka virtual seperti $\mathrm{ms}$-team, namun dengan metode $e$ learning, fitur pembelajaran berupa materi yang diberikan sangat beragam dan lengkap, hal ini ditandai dengan adanya bank soal. Interaksi 2 arah juga dapat dilakukan pada media e-learning dengan menggunakan fitur chatting. Metode selanjutnya yang disukai adalah menonton video pembelajaran yang telah disiapkan dan diberikan oleh guru, dengan jumlah subjek penelitan menjawab hal tersebut sebanyak $9,1 \%$

5. Bagaimana pendapat anda mengenai pernyataan berikut ini: "Penyampaian materi dalam pembelajaran daring mudah dimengerti”

Pertanyaan ini mewajibkan subjek penelitian untuk menanggapi pernyataan yang diberikan. Adapun terdapat 4 pilihan, dari tingkat sangat setuju sampai sangat tidak setuju. Dari pernyataan ini akan diketahui pendapat dari siswa, apakah dengan metode daring yang diterapkan selama pandemi ini, materi yang diberikan dan disampaikan oleh guru sudah bisa dengan mudah dimengerti apa tidak oleh para siswa. Hal ini penting sebagai dasar evaluasi proses daring yang berlangsung selama pandemi covid-19 yang sudah 
berlangsung kurang lebih selama setahun terakhir.

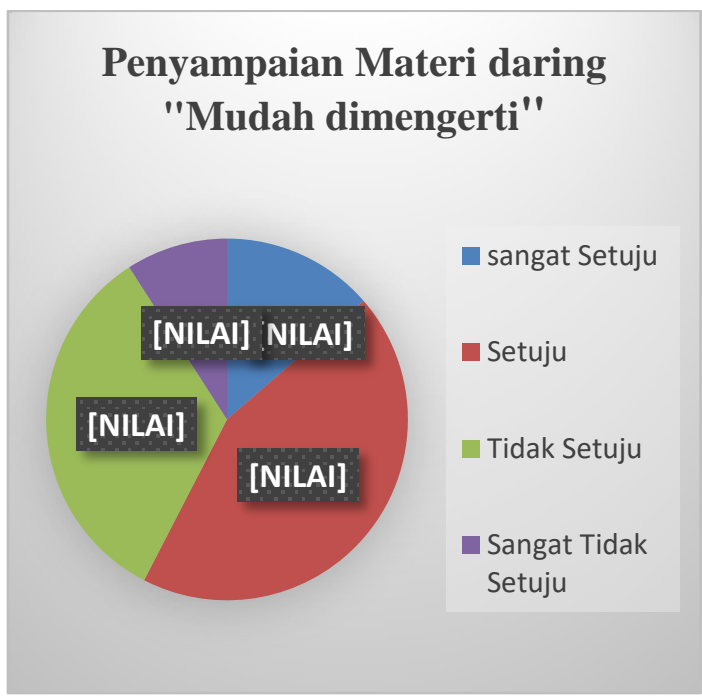

Gambar 3. Hasil Penyampaian Materi Daring.

Dari pertanyaan ini jawaban paling banyak adalah menyatakan "setuju" sebanyak 43,9\%. Hampir separuhnya menyatakan bahwa setuju dengan pernyataan yang diberikan bahwa pembelajaran daring mudah untuk dimengerti. Selain itu terdapat $13,6 \%$ subjek penelitian memberi jawaban "sangat setuju" akan pernyataan dari pertanyaan kuisioner nomor 5 ini. Sehingga bila ditotal sebanyak $57,5 \%$ menerima dan setuju dengan pernyataan pada pertanyaan ini. Disisi lain sebanyak 33,3\% menyatakan "tidak setuju" dan sebanyak 9,1\% menyatakan "sangat tidak setuju" dengan pertanyataan tersebut. Secara garis besar, tentu jumlah yang setuju dengan pernyataan bahwa pembelajaran daring mudah untuk dimengerti jauh lebih besar daripada yang tidak setuju. Hal ini tentu menjadi hal yang positif karena sebagian besar subjek penelitian menggap bisa belajar dengan baik dengan sistem pembelajaran daring yang diterapkan. Meskipun sebagian besar setuju dengan pernyataan tersebut, namun angka presentase yang tidak setuju dengan pernyataan ini masih cukup besar. Hal ini menjadi pekerjaan rumah untuk sekolah dan tim pendidik untuk diselesaikan dan dicari solusinya sehingga daya serap siswa dalam belajar dengan metode daring semakin lebih baik kedepannya.

6. Metode pembelajaran bagaimana yang anda pilih?

Pertanyaan ini adalah pertanyaan terakhir, diamana subjek penelitian diberi pilihan metode pembelajaran yang menurut siswa paling efektif dan paling disukai untuk dilaksanakan selama pandemi ini. Pada pertanyaan ini, siswa diberi pilihan apakah lebih menyukai dan menginginkan metode pembelajaran daring, tatap muka, atau campuran keduanya. Tujuan dari pertanyaan ini adalah murni hanya untuk mengetahui keinginan siswa yang sesungguhnya mengenai metode yang diinginkan untuk dilaksanakan selama pandemi. Dengan diketahuinya keinginan siswa dari data penelitian ini, meskipun nantinya akan dilaksanakan metode pembelajaran yang tidak siswa inginkan karena hal tersebut menjadi peraturan pemerintah, pihak sekolah dapat mengambil pendekatan yang intensif dan tepat kepada siswa, sehingga pembelajaran dapat tetap berlangsung baik dan efektif meskipun tidak sesuai keinginan siswa.

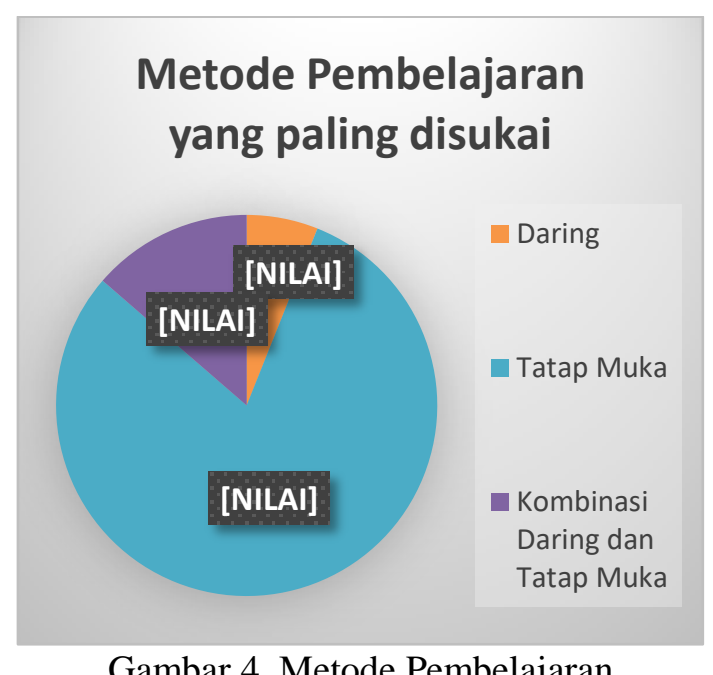

Dari subjek penelitian yang telah menjawab pertanyaan ini, hasilnya menggambarkan bahwa sebagian besar peserta didik menginginkan pembelajaran menggunakan metode tatap muka, yaitu 
sebesar $80,3 \%$. Berdasarkan hal tersebut dapat diketahui bahwa, sistem pembelajaran tatap muka secara konvensional masih dipilih dan disukai oleh siswa untuk proses pembalajaran di sekolah. Selanjutnya metode yang diinginkan oleh siswa kombinasi selama pandemi ini (perpaduan tatap muka dengan daring), yaitu sebesar $13,6 \%$. Siswa menginginkan meskipun pembelajaran diadakan secara daring karena masih dalam kondisi pandemi, tapi sesekali siswa ingin pembelajaran tatap muka untuk refreshing, sekaligus juga dapat berinteraksi langsung dengan teman-teman dan guru. Sisanya sebanyak $6,1 \%$ siswa menginginkan tetap pembelajaran dilakukan secara daring di masa pandemi, dimana siswa mempertimbangkan faktor kesehatan karena masih adanya pandemi dan sudah terlanjur nyaman dengan sistem pembelajaran daring.

\section{KESIMPULAN}

Berdasarkan hasil penelitian dapat disimpulkan beberapa hal sebagai berikut:

1. Sistem pembalajaran online dengan metode daring, di kelas X SMK TI Bali Global Denpasar, dengan media E-learning dan Micrsoft Team menunjukkan hasil yang cukup efektif. Hal ini dapat dilihat dari hasil kuisioner kepuasan siswa. Dari hasil kuisioner ini sebagian besar siswa menjawab cukup puas dengan pembelajaran online di SMK TI Bali Global Denpasar. Sebagian besar siswa memberi respon positif yaitu terdapat $37,9 \%$ yang menjawab cukup puas, $27,7 \%$ siswa yang menjawab puas, $7,6 \%$ yang menjawab sangat puas. Selain indikator kepuasan, sebagian besar siswa juga merasa mudah memahami pembelajaran yang diberikan, yaitu sebanyak 43,9\% menyatakan setuju dengan pernyataan yang diberikan bahwa pembelajaran daring mudah untuk dimengerti. Selain itu terdapat $13,6 \%$ subjek penelitian memberi jawaban "sangat setuju". Hal ini terkait kebijakan dan media yang dipilih oleh tim sekolah SMK TI Global sangat baik. Media yang dipilih merupakan kombinasi antara media E-learning dan Micrsoft Team yang dilakukan secara bergantian setiap minggunya, dimana kedua media ini saling melengkapi dalam menunjang terciptanya pembelajaran yang baik dan efektif . Hal ini dapat terlihat dari penelitian ini, bahwa siswa sangat menyukai metode pembelajaran dengan Micrsoft Team, yaitu sebesar 78,78\%, yang selanjutnya diikuti media E-learning sebesar $12,12 \%$. Kebijakan dan strategi ini cukup baik sehingga pembelajaran online di SMKI TI Global Denpasar cukup efektif dan dapat berjalan dengan baik.

2. Permasalahan terbesar yang dihadapi siswa adalah terkait masalah quota dan koneksi internet/sinyal. Hampir sebagian besar siswa yaitu sebanyak $68,2 \%$ siswa menjawab kendala quota untuk internet dan sebesar $22,7 \%$ adalah permasalahan sinyal atau koneksi internet yang buruk. Hal ini tentu perlu dicari solusi yang tepat, baik dari pihak sekolah dan siswa agar permasalahan ini dapat ditangani dan tidak menggangu proses pembelajaran.

3. Meskipun siswa merasa cukup puas dan mudah memahami pembelajaran yang diberikan secara online, namun diketahui sebagian besar peserta didik masih menginginkan pembelajaran menggunakan metode tatap muka, yaitu sebesar $80,3 \%$. Sedangkan sebesar $13,6 \%$ menginginkan sistem pembelajaran kombinasi selama pandemi ini (perpaduan tatap muka dengan daring), dan hanya $6,1 \%$ siswa menginginkan tetap pembelajaran dilakukan secara daring di masa pandemi. Siswa yang menginginkan pembelajaran tatap muka beralasan karena ingin berinteraksi langsung dengan teman-teman dan guru. Hal ini dianggap lebih menyenangkan oleh siswa. Meskipun demikian jika dilihat dari indikator lain seperti pada yang telah dibahas sebelumnya, sistem pembalajaran di kelas X SMK TI Global BAli Denpasar sudah cukup baik dan efektif.

\section{DAFTAR PUSTAKA}

Auliya, R. N. 2016. Kecemasan Matematika dan Pemahaman Matematis. Formatif: Jurnal 
Ilmiah Pendidikan MIPA, 6(1), 12-22. https://doi.org/10.30998/formatif.v6i1.748.

Chandrawati, Sri Rahayu. 2010. Pemanfaatan Elearning dalam Pembelajaran. No 2 Vol. 8. http://jurnal.untan.ac.id/

Gheytasi, M., Azizifar, A., \& Gowhary, H. 2015. The Effect of Smartphone on the Reading Comprehension Proficiency of Iranian EFL Learners. Procedia - Social and Behavioral Sciences, $\quad 199, \quad 225-230$. https://doi.org/10.1016/J.SBSPRO.2015.07. 510

Hanum, N. S. 2013. Keefetifan E-learning sebagai media pembelajaran (studi evaluasi model pembelajaran e-learning SMK Telkom Sandhy Putra Purwokerto). Jurnal Pendidikan Vokasi, 3(1), 90-102. https://doi.org/10.21831/jpv.v3i1.1584

Kementrian pendidikan dan kebudayaan Republik Indonesia. 2017. UU No 20 Tahun2003. http://kemdikbud.go.id/index.php/peraturan 1/8-uu-undang-undang/12-uu-no-20-tahun2003-tentang-sistem-pendidikan-nasional diakses 7 januari 2020

Krisna, E. D dan Marlinda,M .2020. Implementasi Problem Based Learning berbantuan Google Classroom Untuk Meningkatkan Prestasi. PENDIPA Journal of Science Education, 2020: 4(3), 91-97

https://ejournal.unib.ac.id/index.php/pendip a/article/view/12447/6211
Kuntarto, E. (2017). Keefektifan Model Pembelajaran Daring dalam Perkuliahan Bahasa Indonesia di Perguruan Tinggi. Journal Indonesian Language Education and Literature, 3(1), 53-65

Sari, P. (2015). Memotivasi Belajar Dengan Menggunakan E-Learning. Ummul Quro, 6(2), 20-35.

Situmorang, Adi . 2020. Microsoft Teams for Education Sebagai Media Pembelajaran Interaktif Meningkatkan Minat Belajar. Sepren: Jurnal of Mathematics Education, Vol 2 No 1 (2020): September 2020 https://jurnal.uhn.ac.id/index.php/sepren/article/v iew/351

Suherman, Erman dkk. 2003. Strategi Pembelajaran Matematika Kontemporer. Bandung: PT Remaja Rosdakarya.

Surat Edaran Menteri Pendayagunaan Aparatur Negara dan Reformasi Birokrasi (PAN \& RB) Nomor 50/2020 tentang Perubahan Kedua atas Surat Edaran Menteri PAN \& RB Nomor 19/2020.

Widiyarso,TH. 2021. Efektifitas Penggunaan Microsoft Teams Dalam Pembelajaran ELearning Bagi Guru Selama Pandemi Covid-19. DIDAKTIS: Jurnal Pendidikan dan ilmu pengetahuan, Vol 21 no 1 (2021). http://journal.umsurabaya.ac.id/index.php/di daktis/article/view/5283

World Health Organization. Covid-19 Weekly Epidemiological Update, 21 March 2021. 